\title{
An Empirical Study of Factors Influencing Election in the Rural Government in China-Case Studies of Four Villages in China
}

\author{
Yuan LIU \\ PhD Candidate, Faculty of Philosophy and Social Sciences, Université libre de Bruxelles, Brussels, \\ Belgium
}

\begin{abstract}
Election fraud has been a topic of much attention. Through investigation of four villages in Shanxi province in China, this study made an empirical analysis of issues regarding the election fraud of villages. Based on the data analysis, this study is devoted to discussing five research questions, including general evaluation of villagers on election fraud, correlation between clanism and fraud in election, correlation between economic level and election fraud, the strategy of winning the election for the candidates, the cost of the village's election and the sources of its funding. Analysis of questionnaire and interview comes to the following conclusion. Firstly, generally, in these four villages, there exists different degrees of fraud happening in election. Secondly, it is found that there is no significant positive link between clanism and fraud in election. Thirdly, economic level, diversification of economic type and economic interests have an effect on election fraud, which also reduced the clanism's influence on election. A qualitative analysis based on the interview indicates that electoral system does stimulate the candidates to employ democratic means and political art to deal with the relationship of different sorts. The economy is the foundation of election. However, the state government does not bear the funding for election, which may lead to some corrupt acts. The improvement of local democratic politics needs the government's neutral position and effective measures. Therefore, how the government can solve the problem of raising funds for election should be paid attention to. There is no guarantee of democratic politics without the financial foundation. An electoral system, which is reasonably managed by the government, can lay a good foundation for a just and healthy local democracy in election.
\end{abstract}

Keywords: election, fraud, rural area in China, economy, clanism.

\section{Literature RevieW ON ELECTION IN RURAL GOVERNMENT IN CHINA}

After market-oriented economic reforms from 1978, fundamental changes have taken place in the structure of China's economy and society. "In rural areas de collectivisation, the rapid spread of the "household responsibility system" and the relaxation of controls over rural-urban mobility gradually altered not only the previous collective systems of agricultural production but also the political, administrative and social fabric of village life. Though the 1982 Constitution sanctioned the idea of elections for village committees, there was no legislation, detailed regulations or procedures in place to guide the conduct of elections. Against this background of politico-administrative restructuring and market incentives the management of village affairs became increasingly ad hoc" (Jude, 2007). It has been 20 years since election system was adopted in the appointment of village committee director in the Chinese rural government. In form, the rural village committee election is similar to the democratic election system of Western society, which applies the rule "one person for one vote, public election". However, a body of evidence demonstrates that the operation of election in Chinese rural government is not so ideal as expected, which is affected by many factors such as traditional kinship relation, personal social network and so on. In order to better dominate the scarce resources in the village, the clan is keen on seeking to win official positions in the village committee elections through various means. In order to achieve this purpose, bribery election has occurred sometimes in a fierce campaign, even accompanied by violence or malicious exclusion.

In Chinese history, state power does not reach the county level, which means that only in towns and villages, local autonomy is implemented. Nevertheless, this sort of autonomy is actually realized under co-governance of the squire and circles of kinship and clan known as the "Presbyterian rule"(Wu Han, Fei Xiaotong, 1988; Zhao Xiuling, 1998). In the clan-autonomy practice, rural society breeds hundreds of years of clan kinship and cultivates a rich kinship-dominant culture, thereby 
solidified into a clan-dominant power system (Thurston, 1998). Until the founding of the people's Republic of China, the central government has tried to extend the power into rural areas, but failed to change the role of clanism in rural governance (Du zanqi, 1994; Chen Hansheng, 1984; Freedman, 1958).

Social differentiation between clans and within clan affects the operation of the rural society at present. National cadres, village cadres' power has penetrated into the clan activities, which leads to the result that those who have power can even change the fate of the whole clan. Clanism, to some extent, has become the ruling resources (Li yongji, 1996). Zhu Qiuxia (1998) did the survey of six villages, showing that in those villages with a dominate majority clan, the clan as an informal organization is actually simultaneously the administrative village as formal organization. Some minority clans attempt to participate in the distribution of power in the administrative villages, with a role in a network of clan. In the village-level democratic elections, most rules tend to ensure the winning of candidates of majority clans, which constitutes a prominent problem with the village democracy proposed by the clans. The majority clan will "eat" small one, while it is difficult for the real competent candidate to get favored by voters. Especially in some places under rampant influence of the clanism, due to the clan cultural concept, it has become the established fact that democratic election is decided by the clanism influence (Zhu hong, 2001; Sun jugao, 2001). To this end, Zou Ziying (1997) asserted that the emerging clan forces would not be a positive social force to promote the development of democracy. Some scholars even observed that the election of a village stimulated village factional strife, clan competition, even village bully forces fight (He Qinglian, 1998; He xuefeng, 2001).

And some scholars found that the impact of clanism on the election is an objective existence, but it is non-organized, informal. It is indicated in two ways. On the one hand, candidates and their supporters regard the clan relationship as competition resources and means for electoral success; on the other hand, voting of villagers reflects clanism psychology and clanism orientation. However,The clanism influence on the election is actually weak, fragmentary in the form of spontaneous individual acts, or non-organized mass behavior, which is not organizational competition based on clan-relation (Xiao Tangbiao, 2002). Clans in the election tend to conduct the underground activities and it is possible to make conflict publicized, but its supervision on the course of the election is evident. From this point of view, the functions of clanism will change with the transformation of the society. He argues that the higher the proportion of the population of different clans is, the more differences on village affairs may be caused within the village, which thus have an incentive to use new system of elections in the coordination of conflicts of interests. Yao (2013) illustrates the dynamics of politics in the village, especially factionalism, since the beginning of direct elections and the rise of village toughs and predatory entrepreneurs in recent years and the damaging effect of the latter on the village's socioeconomic order and democratization.

In addition, many scholars have devoted themselves to the cause-effect relationship between economic level and village democracy. Lai jianli (2007) believes that those villages which have outstanding collective enterprises tend to be the village of autonomy by the villagers, because the collective enterprise operators have easier access to the trust of the villagers. He points out that the election may be the potential way and channel for the elites rising after the reform and opening up of rural economy to gain political power at the lower political power structure, and therefore they are motivated to promote election, even making use of various means including bribery to win the election. It is also argued that economic level itself may not definitely be able to bring political development. The region of the economic backwardness will more seriously practice democratic elections, in order to consolidate the political foundation of poor rural areas. In addition, Yao (2013) examines a series of four direct elections and their impact in a poorly governed Chinese village near Beijing, who identifies the main contradiction in the village, is that of economic justice between villagers on one side, and the old and elected officials, and village toughs and predatory entrepreneurs, on the other.

Based on the literature, this study will testify whether there is a significant correlation between the clanism, economical level and fraud in election of the rural government in China.

\section{RESEARCH DESIGN AND QUESTION}

Through investigation and observation, this study made an empirical analysis of issues related to the election of village. For a period of two months, we carried out the investigation of the village election 
in four villages in Shanxi Province in China and collected a total of 432 valid questionnaires, and a large number of first-hand data. Investigation involves many aspects of election. This study is mainly devoted to addressing five research questions, in order to testify the above-mentioned hypotheses concerning the democratic election in the rural government.

\subsection{Villages Selected for Case Study}

This study selected four villages in Shanxi Province as cases, respectively A, B, C, and D. The reason why these four villages are selected is that differences between the four villages can meet our purpose of exploring the correlation of different variables and rural election fraud. Now different situations of four villages are listed below in terms of location, degree of urbanization, economic development, collective enterprise, and economic income of villagers.

Table1. Overview of Four Villages

\begin{tabular}{|l|l|l|l|l|l|}
\hline Village & Location & Urbanization & Economic development & $\begin{array}{l}\text { Collective } \\
\text { enterprise }\end{array}$ & $\begin{array}{l}\text { Economic } \\
\text { income }\end{array}$ \\
\hline A & within city urban area & completely & high & yes & high \\
\hline B & city Suburban area & partially & intermediate & yes & intermediate \\
\hline C & mountainous area & no & low & no & low \\
\hline D & county Suburban area & partially & intermediate & no & intermediate \\
\hline
\end{tabular}

From the table, it can be seen that these four villages have their specific characteristics, which are different from each other in some parameters so as to render it possible for us to investigate the correlation between these parameters. To be specific, A is a village which is located within the urban area involved in the process of urbanization, with a developed economy. Its original farmland has been changed into the commercial land for building apartments, which brings the villagers a yearly bonus out of the interests of land transfer. In addition, this village has run its own collective enterprise. Secondly, B is a village located on the outskirts of the city, partially involved in the process of urbanization. Its economy has become better than before, with part of original farmland changed into commercial land. It also has its own collective enterprises. Thirdly, $\mathrm{C}$ is a remote village, which is located in the mountainous area with no urbanization at all. Villagers still make a traditional agricultural living. Moreover, most of the young people have left down the mountain for a better living. Fourthly, D is a village near the county, partially involved in the process of urbanization, whose villagers mainly make a traditional agricultural living.

\subsection{Research Question}

Five research questions will be addressed in this empirical study of election fraud in rural government in China. Through answering these questions, we can present a relatively objective picture of the operation of election in rural government in China.

(1) What is the general evaluation of villagers on election fraud?

(2) Is there a significant correlation between clanism and fraud in election in villages? How is the influence of clanism on the rural election?

(3) Is there a significant correlation between economic level and election fraud? If yes, is it positive or negative?

(4) What is the strategy of winning the election for candidates?

(5) What is the cost of the election and the sources of its funding in villages?

\subsection{Methodology}

Generally, questionnaires are done by villagers, in which questions concerning those abovementioned factors are covered. On the one hand, their perception of election fraud is investigated through the questionnaire. Since in this study, we want to make a comparison of the degree of fraud of four villages, which is an abstract concept that is difficult to measure. Therefore, in order to quantify this concept, some indexes are design in the questionnaire to make its scale. For the degree of economical level, we will use the average income of villagers as the index in order to see the correlation between economical level and election fraud. For these aspects, the quantitative analysis will be employed in order to make the analysis objective. 
In addition, for the fourth and fifth research questions, the interview will be also adopted. For these aspects, the qualitative analysis will be made in order to explore deeply the source of the fraud. Generally, both questionnaire and interview are needed for this empirical study. For the different research questions, either quantitative or qualitative analysis will be needed in order to offer a comprehensive overview of this issue of election fraud in the rural area in China.

\section{RESULT AND DISCUSSION}

In this section, based on the qualitative analysis and quantitative analysis of the data, the results of these research questions will be presented and discussed.

\subsection{Perception of Villagers on Rural Election Fraud}

Basically, perception of villagers on fraud in rural election is given a comprehensive analysis from four specific indexes. The valid questionnaires are collected of 124, 122, 84, 102 participants respectively in these four villages. In the questionnaire, the following aspects are investigated in order to make a comprehensive exploration of their evaluation of election fraud in their own villages.

Firstly, participants are asked to give their opinion of the fairness of the election.

Table2. Survey of Fairness of Election

\begin{tabular}{|c|c|c|c|c|c|}
\hline Village & Very fair & Fair & Not fair & No idea & Total of negative \\
\hline A & $3.5 \%$ & $11.3 \%$ & $84.7 \%$ & $0.5 \%$ & 84.7 \\
\hline B & $5.8 \%$ & $20.6 \%$ & $72.4 \%$ & $1.2 \%$ & 72.4 \\
\hline C & $14.5 \%$ & $60.7 \%$ & $13.6 \%$ & $11.2 \%$ & 13.6 \\
\hline D & $7.8 \%$ & $26.3 \%$ & $63.5 \%$ & $2.4 \%$ & 63.5 \\
\hline
\end{tabular}

(Note: the total of negative comments refers to the answer "not fair")

Secondly, participants are asked to give their answer to whether someone has given their benefit to ask for the votes.

Table3. Survey of Existence of Bribery Voting

\begin{tabular}{|c|c|c|c|c|}
\hline Village & Yes & No & No idea & Total of negative \\
\hline A & $88.7 \%$ & $9.2 \%$ & $2.1 \%$ & 88.7 \\
\hline B & $78.6 \%$ & $15.8 \%$ & $5.6 \%$ & 78.6 \\
\hline C & $25.8 \%$ & $62.4 \%$ & $11.8 \%$ & 25.8 \\
\hline D & $67.3 \%$ & $24.6 \%$ & $8.1 \%$ & 67.3 \\
\hline
\end{tabular}

(Note: the total of negative comments refers to the answer "yes")

Thirdly, participants are asked to give their opinion of the inspection role of election in the governance of the village director.

Table4. Survey of the Inspection Role of Election in the Governance

\begin{tabular}{|c|c|c|c|c|}
\hline Village & Yes & No & No idea & Total of negative \\
\hline A & $11.4 \%$ & $86.2 \%$ & $2,4 \%$ & 86.2 \\
\hline B & $20.6 \%$ & $74.7 \%$ & $4.7 \%$ & 74.7 \\
\hline C & $64.3 \%$ & $28.6 \%$ & $7.1 \%$ & 28.6 \\
\hline D & $28.7 \%$ & $65.4 \%$ & $5.9 \%$ & 65.4 \\
\hline
\end{tabular}

(Note: the total of negative comments refers to the answer "no")

In order to quantify the degree of fraud during election in these four villages, the total perception score is calculated based on the above-mention three indexes. The calculation rule is that we transfer the percentage of the negative view into the score $(\% * 100)$. The average score of these three aspects will be regarded as the total perception score of fraud.

Table5. The Total Perception Score of Fraud

\begin{tabular}{|c|c|c|c|c|}
\hline Village & Survey 1 & Survey 2 & Survey 3 & Total \\
\hline A & 84.7 & 88.7 & 86.2 & 86.5 \\
\hline B & 72.4 & 78.6 & 74.7 & 75.2 \\
\hline C & 13.6 & 25.8 & 28.6 & 22.7 \\
\hline D & 63.5 & 67.3 & 65.4 & 65.4 \\
\hline
\end{tabular}

(Note: the total refers to the average score of these three aspects concerning fraud in the previous surveys) 
An Empirical Study of Factors Influencing Election in the Rural Government in China-Case Studies of Four Villages in China

Based on the table, it can be seen that different villages has different degrees of fraud happening during election.

\subsection{Correlation between Clanism and Fraud in Election in Villages}

In order to see the influence of clanism on election, firstly the people's consideration of clanism is investigated in their election; secondly, a survey is done concerning whether election can bring benefits to the majority clan. Then based on the result of people's perception of clanism and different degree of election fraud of these four villages, a correlation analysis is done.

Table6. Survey of the Consideration of Clanism in Election

\begin{tabular}{|c|c|c|c|c|}
\hline Village & Yes & No & No idea & The total of negative \\
\hline A & $18.4 \%$ & $79.2 \%$ & $2.4 \%$ & 18.4 \\
\hline B & $10.6 \%$ & $78.6 \%$ & $10.8 \%$ & 10.6 \\
\hline C & $43.7 \%$ & $49.4 \%$ & $6.9 \%$ & 43.7 \\
\hline D & $44.3 \%$ & $43.2 \%$ & $12.5 \%$ & 44.3 \\
\hline
\end{tabular}

(Note: the total of negative comments refers to the answer "yes")

Table7. Survey of Benefits of Election to the Majority Clan

\begin{tabular}{|c|c|c|c|c|}
\hline Village & Yes & No & No idea & The total of negative \\
\hline A & $22.3 \%$ & $73.2 \%$ & $4.5 \%$ & 22.3 \\
\hline B & $14.8 \%$ & $78.3 \%$ & $6.9 \%$ & 14.8 \\
\hline C & $50.7 \%$ & $33.7 \%$ & $15.6 \%$ & 50.7 \\
\hline D & $41.4 \%$ & $47.8 \%$ & $10.8 \%$ & 41.4 \\
\hline
\end{tabular}

(Note: the total of negative comments refers to the answer "yes")

Table8. Correlation between Clanism and Fraud

\begin{tabular}{|c|c|c|c|c|}
\hline Village & Survey 4 & Survey 5 & Clanism & Fraud \\
\hline A & 18.4 & 22.3 & 20.35 & 86.5 \\
\hline B & 10.6 & 14.8 & 12.7 & 75.2 \\
\hline C & 43.7 & 50.7 & 47.2 & 22.7 \\
\hline D & 44.3 & 41.4 & 42.85 & 65.4 \\
\hline r & \multicolumn{4}{|c|}{-0.78} \\
\hline
\end{tabular}

(Note: the score for the clan is based on the previous two survey result; the score of corruption is the total perception score of fraud based on the previous three surveys)

Based on combination of the quantitative analysis and qualitative analysis of the interview, we can see that there is no significant positive correlation between these two factors. The previous literature shows that clanism has a significant negative effect on rural election. This is not consistent with the results of this survey. Only a very small number of people take the clanism into account in voting. Especially, in affluent areas, the candidates of the minority clan can be elected as the village director. Only a small number of people think that the election is in favor of the majority clan members. Clan conflicts, therefore, should not be an excuse to hinder the country's election. Of course, in remote mountainous areas, clanism is indeed more respected than other areas. The conclusion is that many of our views on rural elections are full of a lot of prejudices or stereotypes, out of the lack of scientific evidence to confirm. With the social transition and urbanization, people's value of clanism in their political decision-making has been changed to some degree.

\subsection{Correlation Between Economic Level and Fraud in Election in Villages}

The relationship between economic level and rural election is an interesting mystery. In some places, the demand for economic growth has been the overwhelming request of democratic politics. This study investigates the average income as well the collective enterprise of these villages so as to compare different economic levels of different villages.

Table9. Survey of Economic Level

\begin{tabular}{|c|c|c|c|}
\hline Village & Income/m & Collective enterprise & Commercial land \\
\hline A & 6830 & yes & yes \\
\hline B & 4140 & yes & yes \\
\hline
\end{tabular}




\begin{tabular}{|c|c|c|c|}
\hline \hline C & 2130 & no & no \\
\hline D & 2640 & no & no \\
\hline
\end{tabular}

Table10. Correlation between Economic Level and Fraud

\begin{tabular}{|c|c|c|}
\hline Village & Income/m & Fraud \\
\hline A & 6830 & 86.5 \\
\hline B & 4140 & 75.2 \\
\hline C & 2130 & 22.7 \\
\hline D & 2640 & 65.4 \\
\hline r & \multicolumn{2}{|c|}{0.79} \\
\hline
\end{tabular}

(Note: the number for Income is based on average monthly income per person; the score of fraud is the total perception score of fraud based on the previous three surveys)

The analysis of the data indicates that there exists a significant link between economic conditions and rural election fraud. In addition, in combination with qualitative analysis of the interview, the tendency is that in the very rich village, often the Party branch secretary takes power, which makes the election become only a form. In those of middle economic level, election competition is fierce, for example, the case study of B, C. However, in the poorest village, since there is no subsidy or benefits worthy of competition, election is a just legal process, for example, the case of $\mathrm{D}$.

In addition, the type of rural economy has a certain relationship with election fraud. In an affluent village with the collective economy, if the village branch secretary takes power, he can easily manipulate the election process. However, there are always some people who require a fair democratic election, because the election gives them a chance to demand a fair distribution of collective property. Simply economic development or improvement will not lead to the pursuit of democracy. Precisely, a fair distribution of collective wealth based on economic development leads people to support rural elections.

The commercialization of the rural economy, especially the urbanization of the rural areas, has a certain impact on the election. When the commerce sweeps through the countryside, the peasants demand a free government, not necessarily a democratic government. The villagers who engage in urbanization show no difference in the way of life with urban residents basically. The city's "formal democracy" has influenced rural election, and in many cities and towns, the election is a pure form. In this case study, A is of this type.

The level of economic development has an impact on the role of clan factions in rural election. A dispute over an election due to sectarian forces has mostly occurred in remote and impoverished mountainous areas. On the contrary, in the village of high economic level, diversification of economic type and economic interests has reduced the clanism's influence in election, like A and B.

Family income also has a link with the election. The poll results show that when the family income is low, its proportion of "don't know electoral law" is higher. Generally speaking, statistics tells us that the farmers' political participation degree is proportional to the farmers' family income. The conclusion is that economic level, economic type, and income level have complex and diverse effects on rural election process. Economy has a great effect on rural democracy. However, what is found in this study is different from the study with the micro survey of 698 voters in 30 rural election districts done by Pierre F. L, Deborah D, Shiru W (2010), which demonstrates that village wealth and geographical isolation also do not demonstrate a strong substantive impact. It may be due to a lot of the contextual differences of the cases investigated.

\subsection{The Strategy of Winning the Election}

Election has an impact on the way of political behaviors of the candidates. In the absence of electoral mechanisms, most of the village cadres tend to take care of the interests of upper officials as a main strategy. However, when there are opportunities for the election of village directors every three years, election of directors depends on whether they can get the votes of the majority, so to take care of the interests of the average villagers is the main strategy of candidates in order to win the votes. Even in order to get the support of villagers, sometimes they tend to defend the interests of the villagers. "Caring downward" is more important than "climbing upward", because the village is foothold root for election.

Below I will illustrate the winning strategies based on the interview of these village directors. Base on their interviews, the following several successful experiences are summed up. First, to be elected, they 
should usually focus on doing good deeds. If they want to win re-election, there will be more pressure for them to make better achievements. This is the main source of winning votes. Second, in the election, they focus on the winning those indefinite votes. There is no need to do the persuasive work for their firm supporters and opponents. A private campaign team (about ten members) is established to work for the election, for example, to prepare election expenses, and treat the voters dinner and give out the benefits for the votes. Third, they should raise the campaign slogan, which can motivate the voters by promising that they will lead the village to be more affluent, earning them a rich living. Fourth, after succeeding in the election, the village director should not monopolize power, but rely on the village committee members to accomplish the work together. Through decentralization to other people, they can get the support of these people and reduce their burden of work.

Owing to the limitation of the content of interviews, the summary may be not so comprehensive. However, base on the summary, we may come to the following conclusions. Firstly, electoral system does stimulate the village cadres to employ democratic means and political art to deal with the relationship of different sorts, which is the product of the reality of rural politics. Secondly, the economy is the foundation of election. If there is no funding support, it is much more difficult to win the election for the candidates. This reminds us of Lenin and Marx's criticism of the democratic system: democracy is just a paradise for the rich. Thirdly, the political behavior of winning votes of villages also produced another negative phenomenon: candidates tend to give some benefits to the villagers to prevent the loss of votes. The problem is where is the source of the benefits, which may leads to corruption. In the following section, the results are presented regarding the cost and source of election.

\subsection{The Cost of the Villagers' Election and the Sources of its Funding}

The two main contents of democratic politics are public participation and political competition. Participation and competition cannot be separated from the money. Based on the interviews of villagers, it is found that in each election campaign, villagers get paid a certain amount of money or get some material subsidies. Those villagers who like the election most may be the elderly. An old lady excitedly said that the money she received for the election could cover her one or two months of living expenses. Where does the money come from? The state does not bear the funding for the election of the villages, because the village committee organization belongs to the autonomous unit and the village director is not within the national financial system. In the long run, election expenses will shift actual burden on peasants. If we say that the farmers themselves bear huge funding for the election, then why do farmers want to do this? Here it involves a profound problem, that is, every election is actually a chance to redistribute the wealth of the village. The deeper meaning of wealth distribution is that those candidates who have rich family background will buy tickets by gifts, treat. Wealthy individuals create their own gang groups through personal wealth for election.

Behind political competition is competition of wealth. The result will depend on who can afford to spend the money and how much money to spend. A village director told me that he usually needed to spend a good amount of fund to ensure his votes. There is a lot of criticism in society. But a vote can be changed into a form of wealth, and in itself it has been better than the past, and at least the political rights of farmers have been recognized in this form of distortion.

Currently, the Chinese government is cracking down on election fraud. A dozen cases involving" buying" votes have been seized. It is extremely necessary for the government to come forward to maintain the fairness of the election. The improvement of local democratic politics needs the government's neutral position and effective measures. However, how the government can solve the problem of raising funds for election should be paid attention to. For western democratic party, election funds derive from three sources: state funding, party membership fees and private donations. Nevertheless, Chinese villages' election funds are mainly borne by the farmers themselves. Perhaps, the government should first consider the establishment of a village election expenses fund. Secondly, they should also take into account how to reasonably manage private flows of election expenses. There is no guarantee of democratic politics without the financial foundation. However, election under the control of the dark money forces will produce an unfair "democratic" political election. On the contrary, an electoral system, which is reasonably managed by the government, can lay a good foundation for a just and healthy local democracy. 


\section{Conclusion}

Based on questionnaires and interviews of four villages of different characteristics, this empirical study investigates five questions concerning factors influencing election in the rural area in China. Firstly, generally, in these four villages, there exists different degrees of fraud happening in election based on the villagers' perception of the election situation in their own villages. Therefore, we can see it is the truth that election in these rural areas involves some unfair procedures. Secondly, based on the correlation analysis between clanism and fraud in election, it is found that there is no significant link between these two factors, which indicates that economic development has changed people's concept and value of clanism. Thirdly, economic level indeed has an effect on election process in the rural area. The tendency is that the more affluent the village is, the more likely election fraud is to happen. In addition, the type of rural economy has a certain relationship with the election. Economy with collective enterprise will make it more likely for the person in power to manipulate the election process. The commercialization of the rural economy, especially the urbanization of the rural areas to a certain degree may lead to "formal democracy". Moreover, in a sense, economic level, diversifycation of economic type and economic interests have reduced the clanism's influence in election. Generally speaking, the farmers' political participation degree is proportional to the farmers' family income. A qualitative analysis based on the interview indicates electoral system does stimulate the village cadres to employ democratic means and political art to deal with the relationship of different sorts. The economy is the foundation of election. Village directors tend to give some benefits to the villagers to prevent the loss of votes. The state government does not bear the funding for the election, so the cost of election may lead to corruption. The improvement of local democratic politics needs the government's neutral position and effective measures. However, how the government can solve the problem of raising funds for election should be paid attention to. An electoral system, which is reasonably managed by the government, can lay a good foundation for a fair and healthy local democracy.

Village elections are presently at a crossroad: processes and rules still must be improved. Otherwise, it will only undermine the credibility of village elections. Reform of village electoral institutions should be given a priority in rural political development. Tan (2009) argues for the establishment of a national electoral commission assuming responsibility of implementing, supervising, and adjudicating village elections and initiating candidate-initiated and candidate-centered elections as well as altering campaigning and the 'two majority' rule, proposing the synchronization of election dates since a fixed election date may attract more media coverage, and foster civic culture. Kevin J. O, Rongbin H (2009) suggests that a purely procedural definition of democracy is problematic for election procedures in rural China though it has improved greatly over the last 20 years, proposing that democratization depends on the power configuration in which elected bodies are embedded. They put forward that putting grassroots democracy into place goes well beyond getting the procedures right, and 'high quality' democracy rests on much more than convening good village elections every three years. Therefore, to fight against fraud in election in the rural government in China involves a great number of factors or forces.

\section{REFERENCES}

[1] 陈翰笙.关系资源及农民的非农化-对浙东越村的一项实证研究[M]. 中国社会科学出版 社,1984.

[2] 杜赞奇.文化、权力与国家[M].江苏人民出版社，1994.

[3] 何清莲.农村基层社会地方恶势力的兴起[M].中文大学出版社，1998.

[4] 贺雪峰.派性、选举与民主规则和民间化[M].天津人民出版社，2001.

[5] 赖坚立, 高新军. 谁赢得了村级选举和为什么会赢得这个选举[J], 马克思主义与现实, 2007(6).

[6] 李泳集.权力与资源：广东农村干部研究[D].香港中文大学博士学位论文， 1996.

[7] 孙聚高.试论消解宗族观念影响的现实对策[J].社会主义研究,2001(3).

[8] 吴晗,费孝通.皇权与绅权[M]. 天津人民出版社， 1988.

[9] 赵秀玲.中国乡里制度[M].社会科学文献出版社, 1998 . 
An Empirical Study of Factors Influencing Election in the Rural Government in China-Case Studies of Four Villages in China

[10] 肖唐镖. 宗族、乡村权力与选举 : 对江西省十二个村委会选 举的观察研究 $[\mathrm{M}]$.西北大学 出版社, 2002.

[11] 朱秋霞.家族、网络家族和家族网络在村庄行政权力分配中的作用[J].中国社会科学, 1998(23).

[12] 朱虹.乡村宗族文化兴起的社会学分析[J]. 学海,2001(5).

[13] 邹子婴.中共农村党组织新兴家族和基层民主[C].哈佛大学两岸地方民主比较研讨会论文, 1997.

[14] Freedman, M. Lineage Organization in Southeaster China [M]. Brstol : University of London Press, 1958.

[15] Jude H. Village elections in china: recent prospects, new challenges [J]. Études rurales, 2007, (179).

[16] Kevin J. O, Rongbin H. Path to Democracy? Assessing village elections in China [J]. Journal of Contemporary China, 2009, (18).

[17] Pierre F. L, Deborah D, Shiru W. Elections in Rural China: Competition without Parties [J]. Comparative Political Studies, 2010, 43(6).

[18] Qingshan Tan. Building Democratic Infrastructure: village electoral institutions [J]. Journal of Contemporary China, 2009, (39).

[19] Thurston, Anne F. Muddling toward Democracy: Political Changein Grassroots China [M]. Washington : United Sates institute of Peace, 1998.

[20] Yusheng Yao. Village Elections and Their Impact: An Investigative Report on a Northern Chinese Village [J]. Modern China, 2013, (18). 